\title{
Músicas de lo cotidiano en la poesía de Tomás Sánchez San- tiago. Ensayo para una poética.
}

\author{
José Manuel TRABADO CABADO \\ Universidad de León
}

\section{Uno ha sido silencioso coleccionista de charcos Tomás Sánchez Santiago}

A estas alturas la poesía de Tomás Sánchez Santiago no necesita reivindicación alguna ${ }^{1}$. Quienes frecuentan las carreteras secundarias de la lírica y rehuyen las listas oficiales que bajo la "constatación objetiva" de los libros más vendidos parecen proponer un canon de lectura a buen seguro ya habrán observado algunas de las características que hacen de la voz del autor de En familia un timbre personal e inconfundible. No obstante, conviene quizás hacerse eco de las propuestas estéticas y crear un espacio conveniente de resonancia de esta obra a la que quizás no se le esté prestando la suficiente atención.

Sobresale en esta obra la coherencia de un planteamiento mantenido de forma insobornable a través de los años. La existencia de un ideario dota a la escritura de Tomás de un fuerte carácter orgánico que deriva en una suerte de pequeña melodía a la que progresivamente se le van uniendo otros contrapuntos musicales para conformar una sinfonía callada pero rica en matices que buscan una reivindicación de lo cotidiano elevado a motivo literario a través de una contemplación basada en la extrañeza. No busca Tomás sólo centrarse en lo puramente cotidiano sin más ni basar su obra en una especie de costumbrismo sino que en su forma de mirar rescata el soterrado filón de lo misterioso que es captado por un mirada que todo lo humaniza. Es la suya una estética cotidianista tal y como el propio autor parece reclamar:

\footnotetext{
${ }^{I}$ No obstante, el diccionario reciente de Jesús BREGANTE, Diccionario Espasa Literatura Española, Madrid (Espasa-Calpe) 2003 omite su nombre a pesar de estar convenientemente actualizado llegando a incluir autores nacidos en los años 70. La obra de Tomás Sánchez Santiago ha tenido eco en otras antologías como la clásica de Miguel CASADO, Esto era y no era. Lectura de poetas de Castilla y León, Valladolid (Ámbito) o la de Tomás SALVADOR GONZALEZ, Todos de etiqueta, Valladolid (Barrio de las Maravillas) 1986. Más recientemente aparece en Catorce del Poniente en La factoría Valenciana, $n^{\circ}$ 36, Valencia, 1997; Poesía española contemporánea (1975-1995), Madrid (Castalia) 1997; Poeti Europei, Rom (Edizioni del Centro Italiano Arte e Cultura) 1998 y Nacidos en los 50. Antología de poetas zamoranos, y el estudio de Concha M $^{a}$ VENTURA CRESPO, Zamora (Diputación de Zamora) 1998.
} 


\section{J.M. Trabado Cabado}

"Cada vez con más frecuencia voy pensando en la necesidad de desentenderme por completo de los asuntos públicos para irme sumergiendo del todo en mi mundo literario y desde él mirar la vida, cada vez más cansado -yo- de mirarla cara a cara y seguir dudando si los rostros, la ortografía borrosa que distingo en la vida cotidiana es verdadera o una apariencia que se me desmiente en cuanto me quedo a solas y a oscuras. Rilke decía en una de sus Cartas a un joven poeta que quien no sabía extraer material de la vida cotidiana para levantar su obra, no merecía dedicarse a escribir. Es muy probable que así sea (yo he sido siempre un cotidianista de la literatura, del lado de Cortázar, Neruda, Eluard, Claudio Rodríguez...), pero la residencia del escritor [...] ha de ser su propia escritura por encima de su vida civil. Su papel es ése en una sociedad sensacionalista, hipócrita y material: aislarse y escribir, que es otra fórmula de dejar dicho que sólo se vive dignamente contra corriente de tanta pazguatería, de tanto daño ${ }^{2}$.

Como se puede apreciar la postura estética va íntimamente ligada a un compromiso con el hombre y sus lenguajes. En su tratamiento existe una opción ideológica que pasa por evitar la contaminación que deparan las ideas recibidas sin la más mínima reflexión. De ahí que ese examen de lo cotidiano se realice desde la perplejidad de quien observa desde una atalaya construida y defendida por la palabra. En cierta manera, la misión de la poesía que planeta Tomás podría situarse en consonancia con aquello que preconizaba Coleridge de quitar el velo de familiaridad a las $\operatorname{cosas}^{3}$ o con lo que, más tarde y con otros fines, los formalistas rusos denominaron desautomatización en la búsqueda de la esencia del lenguaje poético. No obstante y para evitar apurar los paralelismos entre unos y otros, la propuesta de Tomás Sánchez Santiago difiere radicalmente en el alcance que lo cotidiano posee en la obra literaria. No se trata de una retórica de la plenitud expresiva del romántico ni de la mirada detenida sobre el lenguaje, una

${ }^{2}$ Para qué sirven los charcos, Badajoz (Del Oeste Ediciones) 1999, p.170. Servirían estas palabras de Rilke para establecer un andamiaje estético próximo a lo que propone Tomás Sánchez Santiago: sálvese de los temas generales y vuélvase a los que le ofrece su propia vida cotidiana: describa sus melancolías y deseos, los pensamientos fugaces y la fe en alguna belleza; descríbalo todo con sinceridad interior, tranquila, humilde, y use, para expresarlo, las cosas de su ambiente, las imágenes de sus sueños y los objetos de su recuerdo. Si su vida cotidiana le parece pobre, no se queje de ella; quéjese de usted mismo, dígase que no es bastante poeta como para conjurar sus riquezas: pues para los creadores no hay pobreza ni lugar pobre e indiferente, en Cartas a un joven poeta, trad. J.M ${ }^{a}$ VALVERDE, Madrid (Alianza) 1997, pp.25-26.

${ }^{3}$ Véase el libro clásico de Robert LANGBAUM, La poesía de la experiencia, Granada (Comares) 1996, pp.106ss. 
vez rotos los puentes de la referencia que unían poema a realidad, que proponían los formalistas rusos. Tomás aboga por una retórica que escapa de la grandilocuencia y lo sublime al tiempo que establece un vínculo eficaz y un diálogo perenne con lo que le rodea por nimio que sea. Lo diminuto, lo invisible, lo casual despierta un honda reflexión que cristaliza en la creación poética. Así lo afirma en el texto titulado "De lo maravilloso": Más que nunca, hemos de dejar de ver y empezar a mirar. Y entonces descubriremos otros centelleos insospechados a nuestro alrededor, como ese charco en forma de pez que la lluvia de la noche ha formado bajo el arce del parque que a diario atravesamos. [...] Pensamos entonces, una vez más, en la trascendencia que hay en las formas de las cosas, en su misterio más allá de su prestigio, más allá de la usura [...] Buscar la luz donde otros nos aseguran que no la hay. Untar nuestra mirada con los pegamentos de lo maravilloso que, de tan obvio, ya se ha vuelto invisible ${ }^{4}$.

Esta actitud atraviesa como capa freática los escritos de Tomás Sánchez y basta con hacer una pequeña cala para comprobar cómo mana de nuevo y emerge a la superficie de la escritura de forma explícita. Otro texto significativo es el de "Ruidos" también incluido en el volumen Salvo error u omisión: Debajo de los sonidos, los ruidos. Alzamos la plantilla de las palabras y alli están, como un montón de sombra que nos mira. Nosotros no comprendemos su música silvestre, embarcada en otra armonía secreta, pero estos ruidos de fama oscura proclaman la verdad última de las cosas, su aliento que nunca ha dejado al desamparo del todo al hombre [...]

Se insiste de nuevo en la importancia de lo mínimo. Parece existir un lenguaje secreto en las cosas que hay que aprender a oír. Sin embargo, y como ya se ha advertido, no sólo es esto una postura estética: la dignificación de lo humilde convertido en materia literaria. Existe en todo ello una cuestión de mucho más fuste, una actitud ante el mundo y todo aquello que rodea al hombre. Cuando las personas y los animales se han ido, el hombre es redimido de su soledad a través de esas pequeñas conversaciones que las cosas parecen querer iniciar en la pereza de su rutina cotidiana. La escritura poética -y no sólo ésta- parece, pues, nacer al abrigo de esos pequeños rumores aprendidos. La escritura es diálogo, mirada que se fija, oído atento a lo supuestamente vanal, traducción de lo imperceptible a una retórica de lo humano donde todo parece cobrar nuevo sentido. La escritura se esfuerza por crear una gramática de lo insignificante en la que el hombre logre salvarse del desamparo. Frente a lo excepcional de lo romántico

\footnotetext{
${ }^{4}$ Salvo error u omisión, Segovia (Caja Segovia) 2002, pp.27-28.
} 


\section{J.M. Trabado Cabado}

existe una apuesta decidida por rescatar no parajes inhóspitos, trasunto del sufrimiento, ni lenguajes altisonantes, sino por incorporar al terreno de la lírica un nuevo tono. El tono de la poesía moderna es una media voz, fraseo vinculado con lo cotidiano que, en esta propuesta poética, parece adaptarse con naturalidad a una temática de lo cotidiano elevado a signo que invita a la reflexión:

Ya no interesa el ruido de los hombres (el diálogo repentino mantenido al pie de la escalera, el uso compartido de la intimidad en el ascensor, la posibilidad de conocer los ojos de quien cada mañana se despierta al otro lado de la pared...) [...] En la gradación de los sentimientos, cuando fallan las personas nos volcamos en los animales [...] Pero los animales también desaparecen, y entonces se elige el reino apacible de las flores. Por fin, llegan las cosas con su silenciosa lealtad, que ni el dolor ni la muerte vencen. Las cosas, que sólo tienen puro ruido suyo aunque no lo entendemos.

Acaso por eso debemos saber que todavía nos queda, como un parvulario alegre y turbulento, esta mínima república de los ruidos que recuerdan la vida secreta de las cosas: la madera que se estira en invierno como si escondiera pájaros largos, los carraspeos de la bombilla en la lámpara, el imprevisto eructo de la cañería aburrida. Cuando las personas traicionan, cuando los animales mueren, cuando las flores se secan, nos quedan para siempre esos ruidos tiernos que alivian el excesivo desamparo de vivir de espaldas a los hombres 5 .

Esa traducción de lo cotidiano a lo literario se produce a través de una mirada perpleja, una mirada que el propio autor ha delineado en una doble trayectoria: ante las cosas y ante el lenguaje ${ }^{6}$. Mirada y palabra han de hermanarse en esta forma de entender la poesía.

Todo este caudal de pensamiento que articula ideológica y estéticamente la obra de Tomás Sánchez cristaliza en una serie de metáforas que lo aglutinan y lo traducen literariamente. Una de estas figuras simbólicas es la del charco. No es baladí el hecho de que una colección de textos de difícil adscripción genérica se titule Para qué sirven

${ }_{6}^{5}$ Ibid, pp.59-60.

${ }^{6}$ Así lo escribe en el texto brevísimo "Extrañeza" que forma parte de "Lumbre baja (Retacería de libreta)": El poeta experimenta una doble extrañeza que le invade insoportablemente. A la extrañeza ante la inmediatez convertida en lejanía irreconocible por mor de la mirada se une la extrañeza ante las palabras, que de pronto se invisten de una enigmática oscuridad, de la misma dificultad que tiene un guante vuelto del revés (p.41). En este sentido cabe recordar la fascinación del escritor ante las palabras escritas al revés que le mostró, siendo niño, el barbero y que cobraron sentido al verlas reflejadas en el espejo: Que yo recuerde, fue la primera vez que me fascinó la palabra escrita, en Para qué sirven los charcos, p.36. 
los charcos. En las páginas de otro libro suyo se puede encontrar otro texto que indudablemente aspira a ser su correlato. Se titula "Los charcos" y pertenece a Salvo error u omisión. Los charcos vienen a ser una referencia de lo humilde que vuelve a enaltecerse a través del pensamiento y la mirada comprensiva de lo misterioso cotidiano. El parangón del que se sirve pertenece a Baudelaire y uno de sus poemas en prosa. Allí el objeto de reflexión son las nubes que encajaban dentro de la matriz temática del viaje de tanta importancia en Baudelaire ${ }^{7}$. No es ahora una tendencia al viaje a reinos imposibles lo que busca el poeta, sino quedarse entre las cosas. Tampoco es la nube, reina de los vientos y la altura, el objeto poético. Prefiere el pequeño charco, ventana en el suelo para mirar otros mundos imaginarios y no menos fantásticos, lo que desde aquí se reclama como modelo de lo extraño instalado en el mundo: Observar los charcos o las nubes es entrar en un nuevo lenguaje: el lenguaje de lo inalcanzable, donde el hombre -al contrario que en esa otra vocación acaparadora- es consciente de la dulce fragilidad de cuanto existe, incluida la de sí mismo y su aspiración a trazar cartografías de aparente solidez.

$Y$ ésa es la razón inicial por la que desde muy pronto hemos elegido los charcos del invierno como una de nuestras fijaciones preferidas, acaso la más fascinante de todas. Nos gusta ir a ver charcos de la ciudad como quien va a ver una nueva escultura inaugurada o una fachada recién restituida. Sabemos dónde encontrarlos, conocemos la calidad de sus bordes [...] Ahora se trata más bien de asomarnos a un borde y comprobar que se abre un mundo de ensueño allá donde se pensaba que sólo había agua derrotada ${ }^{8}$.

El charco es, por otra parte, una forma de representación de aquello que es inasible, tal y como lo demuestra la cita de Machado que se trae a colación ${ }^{9}$. Así pues, a la unión de lo misterioso y cotidiano se le une otra de las constantes que planea sobre la poesía de Tomás: la elegía, el rescate de lo ido insinuado en un tono que evita la estridencia. El charco es la fórmula, la imagen que oficia a modo de un aleph borgiano de la "mirada vicaria", de lo escrito en el agua: aquello que se ve pero que resulta inalcanzable: Mirada, en fin, a la

${ }^{7} \mathrm{El}$ texto al que hace referencia pertenece a sus poemas en prosa y lleva por título "El extranjero", Puede leerse en Obra poética completa, ed. Enrique LOPEZ CASTELLON, Madrid (Akal) 2003, pp.364-365.

${ }^{8}$ Salvo error u omisión, op.cit. pp.49-50.

${ }^{9}$ Los versos que se citan de Antonio Machado pertenecen al poema VII de Soledades: "El limonero suspende / una pálida rama polvorienta / sobre el encanto de la fuente limpia, / y allá en el fondo sueñan / los frutos de oro...", Poesías completas, prólog. Manuel ALVAR, Madrid (Espasa-Calpe) 1985, 11ª ed., p.80. 


\section{J.M. Trabado Cabado}

única escritura que nos representa en nuestra escasa firmeza de seres débiles y efímeros: la escritura sobre el agua, delicada y medrosa como el trazo perdido de la caligrafía de un niño sobre el que apenas podríamos respirar sin que se evaporase... ${ }^{10}$.

El libro Para qué sirven los charcos viene a ser una puesta en práctica de la filosofía estética explicitada en otros lugares. Son observaciones de lo cotidiano-misterioso que invitan a la reflexión, lugares en los que asirse para buscar el sentido, algo que pueda permanecer en el tráfago de la vida. En este libro, en el que el texto breve sirve a modo de crisol para troquelar los temas más variados que poseen un punto de convergencia, la mirada del escritor, también se puede examinar la relación que existe entre esa imagen de los charcos y su asociación al invierno como tiempo para la interiorización desde la que emana la creación de la poesía. Ya en el poema pórtico de La secreta labor de cinco inviernos aparece una filosofía sobre lo que el propio título define como poética del invierno. Frente a los meses estivales el poeta parece haber buscado en el invierno el mundo necesario para la indagación poética:

Entre meses desnudos o sin otro plumaje que una lluvia que abolla los peinados, que cuaja en charcos mudos y aprieta aún más la carne contra húmedos respaldos en las cafeterías.

No debo a nadie tanto como le debo al frío. Esta destreza limpia, derecha que en los días color a queso puro nos retrasa la sed y nos descambia la costumbre inocente de sudar, me basta para todo.

Me basta

ocupar la mala fama de estos meses con palabras robadas entre todos, y a sabiendas de que nada es seguro en este reino; y menos todavía

\footnotetext{
${ }^{10}$ Ibid., p.51.
} 
Músicas de lo cotidiano en la poesía de Tomás Sánchez Santiago

$$
\text { flotar en su ceniza }{ }^{11}
$$

De alguna manera este texto provoca las resonancias de la imaginería, ya descrita, de los charcos. Si en el poema aparecen ya "los charcos mudos", en el texto ya citado de "Charcos" también se refiere a la mala fama de los inviernos y su alto valor simbólico para el poeta: Tiene el invierno razones de más para que soportemos la vida mientras él pasa. La mala fama que entre dientes se atribuye a esta estación no le hace justicia, pues en sus días el hombre cae en comunión consigo mismo, en clausura profunda que lo separa de la enajenación [...] del verano y su melodía de resinas calientes ${ }^{12}$. La referencia en ambos textos a "la mala fama" del invierno y su rescate como tema poético crea vínculos que en modo alguno pasan inadvertidos. La profunda continuidad entre filosofía vital y recreación artística establece un rico entramado de textos en los que unos difieren su voz en espera de la palabra de los otros. Así el coleccionista de charcos diseña desde su obra más temprana una poética íntimamente relacionada con el invierno como tiempo para el retiro y reflexión. En este tiempo se instaura posteriormente la soledad como elemento propicio para entablar el diálogo con uno mismo que supone algo esencial en la poesía de Tomás. En esa reclusión, el sujeto poético se desdobla en dos: sujeto que habla, por un lado, y un tú que no es sino la máscara lingüística por medio de la cual el poeta entra en diálogo interior para tomar conciencia de lo ya ido, del paso del tiempo, de la necesidad de salvarse en las cosas del día a día. El sólido planteamiento estético está ya perfectamente asentado desde las primeras creaciones. Con el paso del tiempo se irá modulando, adquiriendo nuevas vías de concreción: de la lírica al aforismo y de éste al artículo en la prensa: son todos pasadizos íntimamente trenzados que responden a una forma de estar en el mundo que toma conciencia de sí $^{13}$.

${ }^{11}$ La secreta labor de cinco inviernos, Salamanca (Universidad Pontificia) 1985, pp.7-8.

${ }^{12}$ Salvo error u omisión, op.cit. p.48.

${ }^{13}$ Así reza un texto incluido en Para qué sirven los charcos: 'Pero qué frío dan las fuentes en invierno', dice La Garza. (p.112). Ante una frase que bien pudiera ser una observación circunstancial, el oído atento del poeta le da otra dimensión de fuertes resonancias en la médula de su concepción poética. Acaso con esa poética del invierno se pueda relacionar otra frase entresacada de lo cotidiano pero trascendida por su alto valor simbólico: Una vieja va hablando sola por la calle: 'La nieve me da mucha tristeza' (También a Cernuda le irritaba, porque le negaba las realidades (Para qué sirven los charcos, p.36). 


\section{J.M. Trabado Cabado}

Ya En la secreta labor de cinco inviernos existe toda una sección de honda raigambre metapoética. No sólo se escribe sino que pronto se inicia una profunda indagación crítica sobre la misión de la poesía que no desaparecerá a lo largo de la obra de Tomás Sánchez Santiago. Destacan textos como el titulado "Ultimátum (que el poeta a sí mismo se concede)" en el que se plantea ya una doble visión de la poesía. Una poesía fácil y autocomplaciente, una tentación para rehuir la vida y vivir definitivamente en el reino inasible de las palabras. Nace como contrapunto a esta visión un sólido compromiso que aúna vida y palabra, que evita la estafa de una retórica hueca para apostar hasta hacer saltar la banca por la creación de un puente que vaya desde los días hasta la retórica. La poesía nace de ese preguntarse y extrañarse ante las cosas. No puede entonces ceñirse a una serie de argucias lingüísticas aprendidas sin que esto suponga traicionar el instinto natural de la escritura. La lírica hunde sus raíces en una forma de ver el mundo, no en una fórmula de reescritura de lo ya anunciado en otras voces. Para traducir esa mirada extrañada el poeta ha de enfrentarse con la tarea titánica y vertiginosa de crear y modelar un lenguaje propio pero construido sobre las palabras ya dichas que parecían dictar, según algunos pensadores, la agonía de la voz singularizada. Se pretende así una colonización de lenguajes existentes, una apropiación de la palabra ya usada. En este intento la labor lírica de Tomás Sánchez Santiago ha buscado con valentía ciertas palabras que pudieran encontrarse fuera de la circulación de las corrientes literarias ${ }^{14}$. Curiosamente este texto puede establecer una relación dialógica con otros con los que comparte sección y en la que, quizás, el lector asista a la tentación de una poesía que sea autorreferencial y elimine cualquier vestigio del mundo que la rodea. Los poemas a los que me refiero son los que llevan por título "Abril. Ejercicios de estilo" y "Delicatesse". En ambos

${ }^{14}$ El propio autor lo ha explicado con claridad: Un lenguaje que intento conquistar para mí solo. Ese es mi esfuerzo desde que consideré que por encima de todo lo demás mi misión era escribir de mí y de lo otro. Desde entonces, intento ocupar un lenguaje y convertirlo en demarcación particular donde cualquiera que lo desee vaya a picotear cuanto quiera a condición de que mejore esa superficie. Intento, como otros escritores, convertir a la lengua de un bien mostrenco en un valor apropiado, pero inmediatamente entregado otra vez a todos para que lo aprendan. I/ Ahora bien: a nadie le ha sucedido que en mitad de un viaje en un transporte público éste se detiene en un descampado y todo el mundo baja a hacer pis a los servicios de un local de carretera, y uno llega ante un rimero de puertas cerradas que ponen w.c., las va empujando y comprueba que todas están ocupadas? Pues algo así me ocurre en la escritura: una vez caído en la conciencia de que no se trata de violar lenguajes ocupados para ser redundantes, uno sólo aguarda a dar con un cubil desocupado y allí mear -digo, escribir- a gusto (en Para qué sirven los charcos, pp.177-178) 
el poema parece construirse atendiendo a normas internas, a una inercia de las propias palabras que en un movimiento de expansión acaban por tejer la red del propio texto. Así finaliza "Abril. Ejercicio de estilo":

No es la casta estimable de este mes,

definitivamente, quien responde

de la necesidad de este poema; ni su reconocida

competencia de enardecimiento de espíritus

propicios puede alarmar a quien quiso en su casa

pasar la tarde en encontrar palabras

que aquello proclamaran.

Basta aceptar que es todo allegadizo y que tan sólo

sucesiones de palabras

han empujado al poema hasta esta pausa ${ }^{15}$.

Sobre esto mismo abunda el poema "Delicatesse" que si bien se iniciaba del siguiente modo: "Tus relaciones nunca fueron bellas / tanto como lo son con las palabras / ahora" posee un final en el que esta "vertiente formalista" parece quedar clara:

Lo mismo que a unos huéspedes que llegan

salpicados de frío, buscas vano

acomodo entre las sábanas

heladas del poema. Y así los vas probando

y los retiras lejos del bastidor.

Los más tenaces te acompañarán siempre

en el invierno hondo de la memoria

lo mismo que astros muertos:

tan sólo acreditados en sus sílabas ${ }^{16}$.

Esta tentación de una poesía que se autogenera en un ejercicio de lenguaje es la que provoca la súbita toma de conciencia y la maldición que el poeta se lanza a sí mismo: "Te lo repito: que un tiempo miserable / gane tu casa, ahuyente tu carnaza / si te sigues vendiendo a las palabras"17. Se explica así en esta secuencia el siguiente poema "Longitud del silencio", reflexión urdida sobre la frase "Mide bien tus pa-

\footnotetext{
${ }^{15}$ La secreta labor de cinco inviernos, op.cit. p.51

${ }^{16} \mathrm{Ibid}, \mathrm{p} .52$

${ }^{17}$ Ibid.p.53.
} 


\section{J.M. Trabado Cabado}

labras" interpretada en un doble sentido: por un lado, el poeta cree ver en ese consejo la necesidad de una búsqueda de la perfección formal enraizada en la métrica: "Cifras y versos / en perpetuo litigio enmascarado", "Las sendas de lo mágico / responden en poesía a juicios aritméticos" y, por otro lado, el poeta llega a una segunda interpretación. La necesidad de guardar silencio, es decir, de un despojamiento de aquellas palabras que podían deslumbrar por sí mismas, ser sustitutas del referente en un juego de espejos en que la escritura se complace en no mirar nada que no sea trasunto de su propio reflejo. Será el poema "Conclusión y recuento" que cierra esta sección de La secreta labor de cinco inviernos el que ofrezca el camino definitivo: "Y del encontronazo, una enseñanza: / mengua el asombro cuanto crece el hábito" ${ }^{\text {"18 }}$. Frente a unos usos poéticos como los de la Generación de los novísimos, generación del lenguaje también llamada, se esboza una poética que va a contracorriente y que no se deja seducir por los cantos de sirenas de las reflexiones semióticas y metaliterarias que hablaban de crisis del lenguaje ${ }^{19}$. Se propugna así una nueva visión en la que la palabra poética actúa como antídoto contra el hábito de los usos del mirar sin ver y del hablar sin decir. Se pergeña así un intento de radicalizar el lenguaje, de llevarlo a sus secretas galerías para hacerlo germinar de nuevo con todo su poder genesíaco.

Parte de esa radicalización del lenguaje se expresa en el oído atento que el poeta presta a todas aquellas palabras que le rodean en la vida cotidiana. Son numerosas las ocasiones en que muestra la sorpresa ante lo que alguien dice. Su misión es la de rescatar esas gramáticas poéticas disgregadas en el hablar del día a día para afilar perfectamente la hoja del lenguaje. Sirvan a modo de inventario reducido algunos de los ejemplos tomados de Para qué sirven los charcos:

Figuras apostróficas:

Diego, mientras se lava los dientes: Papá, ¿el sudor nos vigila por la noche?

Feliz endecasílabo ${ }^{20}$.

Fragmento de mi madre en aquella cocina:

${ }^{18}$ Ibid. p.55.

${ }^{19}$ Para un panorama sobre la reflexión metapoética véase el trabajo de Ramón PÉREZ PAREJO, Metapoesía y crítica del lenguaje (De la generación de los 50 a los novísimos), Cáceres (Universidad de Extremadura) 2002.

${ }^{20}$ Op.cit., p. 17. 
Músicas de lo cotidiano en la poesía de Tomás Sánchez Santiago

...una vez que el aceite está caliente se echa la cebolla, y cuando está rendida... ${ }^{21}$.

Me levanto cansado:

Un niño me dice: Hueles a dormido ${ }^{22}$.

Castellano viejo:

Rufino, el cantinero de San Esteban de Gormaz, llamó a la careta del cerdo morruga ${ }^{23}$.

El estribo de la muerte:

Un hombre de Villadiego llamaba la moria a los últimos signos de vitalidad del moribundo -falsos y confusos- antes de expirar definitivamente ${ }^{24}$.

Hablan a gritos en Belorado:

Y Ramona me lo expresa con una hipérbole preciosa: Hablan que se escalabran.

Veo no sé qué de mágico en la ocurrente exageración, tal vez por la proximidad fonética de aquel abracadabra embrujador y cabalístico $(\mathrm{p} .64)^{25}$.

\footnotetext{
${ }^{21}$ Ibid.. p. 19

${ }^{22}$ Ibid. , p. 30

${ }^{23}$ Ibid, p.37.
}

${ }^{24}$ Ibid, , p.57

${ }^{25}$ Ibid., p.64. Otro ejemplo de enorme interés, ya que va acompañado por una valoración del propio autor de ese lenguaje poético y soterrado en el uso común que pasa inadvertido, es el siguiente: Ayer volví a sentir un placer que había olvidado. Estuve escuchando cómo hablaba un labriego de por aquí, al que conozco de un par de ratos, y que me fue mostrando un pueblo abandonado. Esa manera de expresarse, de utilizar imágenes sin saber que lo son ("aquí ha mordido el agua") a la misma altura del resto de su discurso me dejaron mudo, estupefacto como cuando he asistido otras veces a conversaciones parecidas. En una hora usó varias decenas de términos específicos que cualquiera, yo por lo menos, hubiese despachado con perífrasis ramplonas. Esa forma de hablar sacando las palabras naturalmente de la lengua como quien echa mano al bolsillo y reparte tabaco para todos, no es cosa normal de comprobar en casi ningún individuo urbano, y cuando uno la oye queda casi siempre revelada la pedantería o la suficiencia del relator. Al lado de ejemplos vivos como el de este campesino -que no sabe que es tal ejemplo- ¿qué pensar de esos otros ejemplos utilitarios -nada gratuitos- que nos invaden de continuo en los eslóganes publicitarios, las campañas políticas, la economía lingüística de los periódicos...? (p.151152). Otro ejemplo de cuanto digo surge en el momento en el que un albañil pronuncia la palabra enfoscar: Pero de pronto, yo un poco cansado de tanta chalanería de domingo, él pronuncia la palabra 'enfoscar' y de inmediato se me abre como un rayo 


\section{J.M. Trabado Cabado}

Esta misma actitud se puede entrever en su ensayo "Baudrillard en la carnicería" en el que se puede comprobar cómo está latente a lo largo de esta obra una forma de auscultación del lenguaje que está profundamente ligada a la poética esbozada en su lírica. Tras examinar la importancia de la paradoja en el pensamiento y retórica contemporánea: Quizá sea la paradoja la más frecuente manera de irnos librando de la imposibilidad de traducir del todo el rostro del mundo actual, maquillado y promiscuo, defendido y atacado a la vez con las mismas armas" (Salvo error, p.34) y unirla al pensamiento provocador de Baudrillard en sus Cool memories ${ }^{26}$, la mirada del autor se detiene en frases dichas como por casualidad como la anécdota que contaba José Hierro al responder a la pregunta de cuánto tiempo llevaba encarcelado en Santander con la siguiente frase: Pues mire usted, aquí estamos presos... desde que nos liberaron (p.37) o aquella otra en que uno de los hermanos Marx dice a otro: iSi nos encuentran, estamos perdidos! (p.37) para rematar finalmente con la frase de la carnicera que predicaba las excelencias de cierto pollo con el eslogan: "Criado en libertad" (p.38). Puede encontrarse en este texto una fórmula espléndida del maniobrar creador de Tomás Sánchez Santiago. Bajo lo aparentemente banal es posible rescatar todo una imaginería verbal que traduce una filosofía oculta. De lo anecdótico de la espera en la carnicería surge un momento de reflexión en el uso del lenguaje que, amparándose en la auctoritas de Baudrillard, elabora una compleja y potente forma de pensamiento. De la herrumbre de las escenas diarias emerge el sustento necesario para alentar una pequeña filosofía que aboga por una forma de mirar siempre atenta a los misterios del devenir de la calle. Esta dialéctica entre lo cotidiano y lo extraordinario también se cifra en el propio estilo, bifronte en su realización, que marca las conexiones entre lo aparente y vulgar y la capacidad de convertirlo en un signo a través de una atenta observación. Frente a lo puramente descriptivo de la localización de un espacio y tiempo que parece hacer vascular el texto hacia una observación costumbrista se insertan una serie de observaciones enmarcadas entre paréntesis que ofician a modo de una voz que ejerce de contrapunto en la forma de mirar: lo normalizado por la repetición diaria acaba siendo objeto de reflexión modelada sobre un lenguaje inquietante y la vez revelador:

verde de luz en algún sitio, sobre todo por el contexto puramente práctico en que la emplea (p.184).

${ }_{26}^{26}$ Existe una traducción publicada en Barcelona por editorial Anagrama, p. 1989. 
Lo pensábamos ayer en la cola de la carnicería del barrio (las colas de los comercios son ya los últimos oasis donde se nos permite reflexionar sin otra alternativa que la dulce, obligatoria ociosidad de la espera), detrás de las mujeres que elegían con mirada de comadrona tajadas de carne cruda (hay algo inquietante de la sala de disección en toda carnicería) (p.35) ${ }^{27}$.

Son varios los ejemplos a través de los cuales parece querer mirarse lo cotidiano desde esa perspectiva de la extrañeza que cristaliza en este texto en forma de paradoja. No es sólo un procedimiento estilístico que busque la provocación, sino una forma de penetrar en la médula de lo habitual a través de un lenguaje que disecciona sabiamente las apariencias. Este texto es simultáneamente constatación de un hecho elevado a fórmula de pensamiento al tiempo que una puesta en práctica de todo cuanto se mantiene desde una postura teórica.

Si Baudrillard servía como maestro de ceremonias para llamar la atención sobre una práctica expresiva sólidamente enraizada en el discurso y pensamiento actual no son infrecuentes las citas de otros autores en los que de alguna manera se puede encontrar cifrada la poética de Tomás Sánchez Santiago. Así, por ejemplo, una cita que pudiera servir como estandarte de todo cuanto propugna de formas más o menos implícitas el propio autor es aquella del poeta portugués Eugenio de Andrade: "Até o indolente aroma dos fenos / pode alterar o mundo" (p.115 de Para qué sirven...) que pertenece al poema "Acordes" incluido en el libro Oficio de paciencia ${ }^{28}$. Ese olor a heno que puede llegar a cambiar el mundo sirve como santo y seña de cómo entiende el oficio poético Tomás Sánchez Santiago. De igual manera sirve la figura del gorrión del poema de Claudio Rodríguez Alianza y condena ${ }^{29}$ que decide quedarse entre los hombres y tragar todo el polvo del mun-

${ }^{27}$ De igual manera en otros lugares el acto en el que el carnicero muestra la pieza de carne que se compra es tamizado a través de una visión litúrgica: (porque hay algo de consagración visceral en la exhibición - 'Esto es tu cuerpo'- y nos cuesta admitir que nuestro organismo guarde insospechadas semejanzas con la vaca o el cerdo) (p.37).

${ }^{28}$ Trad. José Luis PUERTO, Madrid (Hiparión) 2002, 2ª ed., p.32. En “Música de Astillas" escribe Tomás: Cuando leo a ciertos poetas, me alegro mucho de que hayan nacido y así poder consolarme con su escritura. Pero cuando leo a Eugénio de Andrade me alegro de haber nacido yo. Bajo "Música de astillas" se engloban una serie de textos breves que Tomás Sánchez Santiago leyó durante el recital que tuvo lugar en la Biblioteca de Azcárate. Se encuadró en el ciclo de recitales que con el título Poetas, itinerarios organizó la Fundación Sierra-Pambley. La lectura tuvo lugar el 7 de mayo de 2004. Agradezco al autor la generosidad al dejarme leer el texto todavía inédito.

${ }^{29}$ Claudio RODRÍGUEZ, Desde mis poemas, Madrid (Cátedra) 1984, p.154. 


\section{J.M. Trabado Cabado}

do antes que dedicarse a las alturas. He ahí cómo a través de una fuerza centrípeta el poeta va leyéndose a sí mismo a través de los versos de los otros. Son pasillos a través de los que las palabras de uno y otro acaban estableciendo un diálogo. El poema y la poética son así prácticas de un palimpsesto, palimpsesto éste alejado del bizantinismo intertextual $^{30}$ y más bien relacionado con una forma de entender la poesía como diálogo, como participación ${ }^{31}$ del poeta con quienes escriben, leen, hablan y viven inmersos en un mundo rescatable a través de la palabra.

Este afán de participación que se propone a lo largo de su poesía potencia la idea de que será el autor una figura que quede diluida tras su escritura. En este sentido cabe interpretar el título que le da a su antología de poesía: Detrás de los lápices que el mismo autor explica en otro de sus textos agavillados bajo el título "Lumbre baja" que lleva como subtítulo precisamente el rótulo de su antología: Quien se coloca un lápiz en el bolsillo anterior de la chaqueta no quiere exhibirlo. Sólo pretende esconderse tras esa peligrosa espesura para que el mundo no le vea ${ }^{32}$ (p.42). Quizás pudiera compararse esta actitud

${ }^{30}$ Son clarificadoras las palabras del propio Tomás Sánchez Santiago sobre la desatada intertextualidad lírica: "De esta nueva helenística no ha de quedar apenas nada, más que de escribir bien, se trata ahora de preñar la escritura de referencias difíciles de encontrar o, en caso de que el caletre del escritor no dé para aquello, mostrar una postura diametralmente opuesta : dejar bien a las claras la falsilla, desenterrar versos de segunda mano y mostrarlos tal cual, en expresión indiscutible de un agotamiento creativo que a todos [...] nos afecta de plano. (en Para qué sirven los charcos, p.188).

${ }^{31}$ El propio autor defiende esa labor de participación de la poesía. A propósito de una pregunta que se le formula sobre el significado de la obra y la persona de Claudio Rodríguez, contesta lo siguiente: La poesía de Claudio Rodríguez me interesa tanto como su persona y ambas han significado para mí la comprobación de que es posible acompasar hasta fundirlos los hechos públicos y privados del hombre del siglo XX. Este tipo de fusión engendra aquello que me parece que es lo verdaderamente trascendental en la obra poética de Claudio Rodríguez, a saber, la negación de límites entre el poema como objeto literario y como entidad susceptible de incorporarse a otro tipo de existencia que no se entiende como acción -la acción es individual- sino como participación, tal como el propio poeta ha gustado de anunciar reiteradamente. (en Para qué sirven los charcos, p.187).

${ }^{32}$ En este sentido podrían relacionarse estas ideas del autor con las que propone para el estudio del poeta peruano Emilio WESTPHALEN: La necesaria desaparición del autor como requisito para que se cumpla el destino del poema es en Emilio Westphalen configurante esencial de su personalidad. La exigencia de que ninguna fijación ni dependencia subordine la energía de las palabras a otro fin le lleva a una despreocupación [...] que no es sino la forma mayor del abandono en relación con su aquilatada escritura, "Ejemplo Westphalen", en Falsirena, no 1, (2002), pp.21-37. La cita se encuentra en la p.28. La sintonía entre la crítica y la creación poética en Tomás 
con la de quien toma una fotografía: allí perpetúa su mirada, pero no protagoniza el encuadre. Por esta razón el poeta asume el texto como una otredad, algo de lo que se despojó una vez finalizado su acto de escritura. Desde ese momento advierte su propia perplejidad ante lo escrito; es la suya una indagación desde la lectura, no desde una supuesta intencionalidad que existe antes del poema. Visto así, la escritura es un islote en el inmenso mar de la nada que lo rodea desde el pasado, que no puede apresar, y desde el futuro, que le niega sentido definitivo y estable presidido por una intención del autor: Cuando uno, yo mismo en este caso, hace de un poema un homenaje a fin de justificar ante una posteridad más o menos inmediata su existencia, ha de saber que está pegando un salto entre dos vacíos: el del pasado, que en balde intenta recobrar mediante la escritura del poema, y el del porvenir, que como he contado más arriba acaba siempre por asfixiar las referencias reales a las que la escritura se proyecta. Y entre esas dos oscuridades, un relámpago. El guiño efímero del propio poema en el proceso de su creación. [...] Aquel individuo que lo escribió todo es ya tan ajeno al propio poema como a su casa. Y también es ajeno a este otro que ahora piensa en leerlo como quien contempla un paisaje con ojos de sueño, (en Para qué sirven... p.153) $)^{33}$.

No está tan lejos lo propuesto con las teorías de algunos pensadores como Maurice Blanchot ${ }^{34}$, Roland Barthes que preconizaba la

Sánchez Santiago se hace patente en casos como éste. No sorprende, pues, comprobar cómo un verso de Westphalen encabeza a modo de cita el poema titulado "Tampoco era esta vez" incluido en Lo bastante, op.cit., p.13 y que había sido ya objeto de análisis en el estudio que le dedica a este mismo autor "Ejemplo Westphalen", art. cit., pp.31-32. También se puede observar esto mismo en el texto incluido en "Música de astillas" con el título "Despareciendo": "Escribir / para que tú ya no llegues / a estar". Loc. cit.

${ }^{33}$ Esto mismo se puede comprobar en las palabras que en esa especie de diario fragmentado y en ocasiones destemporalizado que es Para qué sirven los charcos escribe a propósito de la edición de La secreta labor de cinco inviernos: Me hablan de ediciones no venales de lujo, de envíos a universidades norteamericanas ... Todo esto me abruma. Todas estas operaciones de publicidad y mercado no están hechas para mí. Quisiera presentar el libro en dos o tres capitales y regresar a la secreta labor de escribir tranquilamente como quien llega silbando de hacer la compra, echando un cigarro por el camino. Mi labor se acabó con el último verso que decidí: más allá está el terreno del libro donde nadie, ni yo mismo, puede ayudarle (p.144).

${ }^{34}$ Puede verse a modo de ejemplo El paso (no) más allá, Barcelona (Paidós) 1994, pp.66-68. Extracto a modo de cita las siguientes palabras que acaso sean significativas: Escribimos para perder nuestro nombre (p.66). 


\section{J.M. Trabado Cabado}

muerte del autor ${ }^{35}$, Michel Foucault que escribía su famoso artículo "¿Qué es un autor?" o incluso Jacques Derrida o Paul de Man. Se habló entonces de una brecha abierta entre el autor y el sujeto lingüístico que protagonizaba la enunciación ${ }^{36}$. Nada del entramado textual parecía ofrecer garantías para aprehender la vida real del autor. El hiato entre realidad y los signos que pretenden representarla es insalvable y definitivo. Del otro lado, el propio sentido de los signos lingüísticos pareció haber entrado en crisis, caso de Derrida quien auspiciado bajo la desconfianza con que Platón observaba la escritura en su Fedro plantea una forma de leer y escribir que disemina el sentido de los textos en un haz de relaciones con otros textos que parece ser el mapa de un viaje irrepetible. Sin embargo, y aunque esta afinidad parece evidente, se podría marcar las distancias con respecto a estas formas de pensamiento. No se trata de una concepción del lenguaje en el momento en el que éste se retuerce en un escorzo mediante el cual se mira a sí mismo y duda de su capacidad de funcionamiento. Analizar desde el lenguaje el propio lenguaje provoca cierta especularidad, abismo que facilita su puesta en crisis: de ahí la imposibilidad de descubrir la intencionalidad, el sujeto es un sujeto vacío, tan sólo una marca lingüística al estilo de Benveniste ${ }^{37}$. En la poética de Tomás Sánchez Santiago se puede buscar una perspectiva más humanizada de la reflexión sobre el lenguaje poético que se llega a sobreponer a la extrañeza que el autor experimenta con respecto a su propio texto ${ }^{38}$. Si

${ }^{35}$ Pueden leerse los textos de "La muerte del autor" o "De la obra al texto" incluidos en el volumen El susurro del lenguaje. Más allá de la palabra y la escritura, Barcelona (Paidós) 1994, $2^{\mathrm{a}}$ ed., pp.65-71 y 73-82 respectivamente.

${ }^{36}$ Para una visión sobre el sujeto lírico se puede leer el libro compilado por Dominique RABATÉ, Figues du sujet lyrique, París (PUF) 1996 y el volumen coordinado por Fernando CABO ASEGUINOLAZA, Teorías sobre la lírica, Madrid, Arco-Libros, 1999. Puede verse también el volumen colectivo compilado por Germán GULLÓN y Fernando CABO ASEGUINOLAZA, Teoría del poema. La enunciación lírica, Ámsterdam, Atlanta (Rodopi) 1998.

37 Véase Jenaro TALENS y Nicolas SPADACCINI "La construcción de la identidad”, en J: Talens, El sujeto vacío. Cultura y poesía en territorio Babel, Madrid (Cátedra) 2000, pp.31-53.

${ }^{38}$ El poeta, una vez escrito su propio texto, puede reaccionar con extrañeza ante su propia escritura. Se convierte, él también, en un intérprete. Léanse las palabras del propio Tomás Sánchez Santiago a propósito del nuevo significado que cobran para él unos versos suyos: Para qué sirven los charcos, pp.170-171. De igual manera advierte en otro lugar: Cuando dejo de escribir pierdo en mucha medida la capacidad de volver a entrar en la clave de lo escrito. Si lo intento me siento extraño, el libro me ha expulsado de sí mismo. En el fondo se trata del problema de la identidad, yo ya no soy el mismo que escribió aquello. Natalia CARBAJOSA, "Entrevista a Tomás Sánchez Santiago", en Empirenma. Revista de creación, Orihuela, verano-otoño (2003), 
en el ámbito de la temática se apostaba por un inventario que evitaba la tentación de lo sublime y lo elevado, ahora, en el espacio de la creación, el autor no asume más protagonismo que el de escribir. La escritura supone el último escalón. Esta labor humilde de quien fragua en el lenguaje su forma de estar en el mundo puede notarse ya en la propia inercia de los títulos: ya se ha insinuado la humildad y valía de los charcos o la forma de esconderse tras su propia escritura (Detrás de los lápices), pero a ello pueden unirse ahora los ejemplos de La secreta labor de cinco inviernos o el título La vida del topo ${ }^{39}$. La escritura está así entendida como un acto comunitario en la que quien escribe comparte su mirada, la ofrece en un ejercicio de desposesión para quien esté dispuesto a asumirla. No es la época de los grandes descubrimientos, ni de las epifanías sobrenaturales, la pequeña importancia de lo oculto en el gris transcurso de los días es ahora territorio de encuentro entre quien escribe y quien lee.

En solidaridad con esta concepción poética surge una forma de entender el lugar del escritor en la sociedad actual. Frente a quien desparece tras haber escrito existe otro tipo de escritor que se impone sobre su producto. Nace así un escritor que se asimila a las operaciones de marketing y su nombre viene a ser logotipo de marca. La vida civil excede y se superpone al propio texto literario ahogándolo bajo la parafernalia de todo lo postizo que rodea a la escritura poética asediándola hasta reducirla a torpe materia inerte ${ }^{40}$.

pp.28-30 (p.28). En esa línea se comprende perfectamente las palabras del texto incluido en "Música de astillas": Ya no es que tenga la certidumbre absoluta de que nunca más voy a saber escribir poesía; es que cada vez me pregunto más si fui yo quien alguna vez la escribió, pues me parece que fue otro el autor de todos mis versos. ¿Mis versos?, loc. cit. Podría ponerse en relación esto con el sistema de comunicación que Yo $\rightarrow$ Yo que propone Lotman: se trata de la autocomunicación. Véase I. LOTMAN, "Sobre los dos modelos de comunicación en el sistema de la cultura", en La semiosfera II, Madrid (Cátedra) 1998, pp.42-62.

${ }^{39}$ Esto mismo es advertido por el propio autor en el transcurso de una entrevista: Al hacer un recorrido formal para la antología portuguesa Detrás de los lápices me di cuenta de que, en efecto, existía un nexo común a todos los títulos. La invisibilidad, la oscuridad, están presentes en mi manera de entender la poesía y la vida. Para mí lo visible es sólo la punta del iceberg y me interesa llegar a la raíz, aun sin despreciar el brillo de las corolas. // Los títulos de mis libros anuncian, pues, algo parecido a una poética. La verdad no está en la apariencia, el mundo de la poesía es el de los lenguajes radicales, no en vano radical viene de raíz. [...] Existe una oscuridad, no programada, que lleva a la simplicidad, un recorrido por el misterio que al final revela la claridad. Natalia CARBAJOSA, "Entrevista a Tomás Sánchez Santiago", loc. cit., p. 28 .

${ }_{40}$ Dice John Updike que el escritor actual, nuevo clérigo de la burguesía dominante, ha asumido esta encomienda con todas sus consecuencias y, por tanto, es con- 


\section{J.M. Trabado Cabado}

Siguiendo esta lógica, la poesía se instala entonces en un lugar marginal dentro de la sociedad actual, más teniendo en cuenta la sugestiva propuesta que Tomás Sánchez Santiago hace de la relación entre lenguaje poético y otros lenguajes utilitarios que hurtan todos aquellos procedimientos retóricos vaciando así las posibilidades expresivas de la poesía. Así se expresa con respecto al papel que cumple la poesía en el entorno social: Irrelevante. El individuo actual tiene multitud de estímulos que le amplían (y le modifican) la capacidad de percepción. Maneras poéticas cuya utilidad se pensaba mucho menos rentable invaden ahora con fines idénticos (excitar la sensibilidad de cada quien) otros ámbitos, sobre todo publicitarios. En los paneles, los anuncios de la televisión, los lemas políticos..., uno ve sinécdoques, hipérboles, antítesis, zeugmas... Con este estado de cosas, la poesía se limita conscientemente a esferas más privadas, más autó-

ferenciante, predicador, en un papel ratificante de su única misión, que sería escribir. La cosas llegan más allá todavía, pues se sigue llamando escritor a quien es solamente homo loquor [...] $Y$, para volver al entrañable autor de Conejo, acaba diciendo que por todo ello hoy se valora más en el escritor el presentar certificado de haber asistido a un curso de redacción de una universidad americana que el haber publicado un libro a la deriva en el maremágnum de todos los días. O sea: al escritor se le exige demostrar oficialmente que está integrado en la industria cultural. Lo otro, lo de escribir y publicar se considera per accidens, como en la vieja fábula. (En Para qué sirven los charcos, p.189). Desde otro ángulo y sin renunciar al humor se viene a decir lo mismo: Me admiro al ver el currículo de algunos poetas. Por ejemplo el de éste, de quien me envían un tarjetón espléndido que anuncia una lectura suya próxima: catedrático en varias universidades europeas, profesor visitante en otras americanas, ensayista, traductor, crítico ... Sí, muy bien, pero ¿qué garantiza de todo ese flemón biográfico que él sea poeta? También hace poco se podría leer en la prensa de uno que tenía cinco licenciaturas. ¿Pero no estorbará tanto título al poeta? Y es que en la literatura española cuenta mucho eso. Como si de un dentista colgase en su consulta el diploma de un curso de acordeón por correspondencia.

P.D. Como caídas del cielo, leo ahora unas palabras de Kavafis: A la poesía antigua le otorgaron -puede que los dioses- el don de silenciar la vida de los poetas. Tomemos nota" (p.42). En esta misma línea se desenvuelve el texto incluido en Salvo error u omisión titulado "Llanto por unos libros" del que extracto tan sólo unas palabras: "Quizás esta amenaza de globalizar también la lectura no sea más que el paso natural tras otros anteriores que en esos terrenos se han dado. El primero de ellos habría sido la profesionalización del escritor, tal como lo desean ahora las empresas y los grupos editoriales. Se trata, ciertamente, de que el autor sea un individuo entregado. Nada de honrados ciudadanos que no quieren perder el paso en la comba de la normalidad. [...] Ahora se trata de salir a la feria con todos los visos de ser un verdadero profesional de las palabras, nada de parecer un escritor pompier de fin de semana. [...] Así que ahora, señoras y señores, se trata de triunfar en el planeta y hay que dar una imagen seria y eficaz de persona que no sólo sabe ordenar palabras sino que sabe negociar con ellas (pp.31-32). 
nomas de todo lo que está bajo sospecha de utilitarismo. Y eso no interesa al común de los mortales ${ }^{41}$.

Este despojamiento de los mecanismos esenciales de la lírica que muy acertadamente observa el autor no significa una desaparición total. Ya se ha visto cómo el oído del poeta y escritor está atento a cualquier frase dicha al azar que supone una intensidad inusitada en el tratamiento del lenguaje. En consonancia con esta actitud puede quizás atisbarse una suerte de retórica latente que está sabiamente camuflada en el poema. Pasando al plano formal no son pocos los poemas en la obra de Tomás que encierran una métrica exquisita, ritmo, sin embargo, atemperado por la ausencia de la rima y enmascarado en un resultado polimétrico. Un poema tomado casi al azar sirve como muestra de cuanto digo. Me refiero al titulado "Las primas carnales" incluido en En familia. Al margen de que temáticamente se centre en algo apenas cotidiano pero tamizado por un sentimiento de pérdida definitiva como es el recuerdo de la visita de aquellas primas se convierte en un objeto de reflexión detenida, en un descubrimiento de otros resortes en la realidad conseguidos gracias a una potente sugerencia de las imágenes: "Desde la luna un óxido / volcaba la amargura por sus trenzas / rizadas como el agua sin fe de algunos ríos"42.

La poesía presenta así un lente capaz de enseñarnos a ver como si fuera la primera vez. Sin embargo, no resulta difícil entresacar ejemplos de endecasílabos que bien pudieran pasar inadvertidos junto a otros metros no menos complejos, como el verso alejandrino. He aquí algunos ejemplos de endecasílabos ${ }^{43}$ :

${ }^{41}$ Para qué sirven los charcos, op.cit, p.154. Estas palabras se pueden poner en relación con las siguientes: Pero lo que me preocupa [...] es que estas innovaciones cobran importancia y se introducen en los lenguajes públicos, los que más influyen en el seno social, entonces la lengua poética tenderá a replegarse a otras maneras, por cuanto un hecho estético siempre es una reacción a la norma. Y si esta reacción contra la lengua normal ya se utiliza en la retórica publicitaria y periodística, ¿qué camino seguirá la poesía? Tal vez un nuevo prosaísmo, en el mejor sentido del término. Cuando leo un buen poema actual no hallo imágenes que me exciten los sentidos, no veo que sea un poema hiperestésico, sino una limpieza de tonto, una utilización natural de cada palabra, de cada sintagma, respaldada por una profundidad de pensamiento que, sin embargo, no implica una densidad en el poema, que no es espeso ni solemne ni lento: su corriente no se ve zancadilleada por continuos sobresaltos de contenido y las palabras bajan por el poema ágiles y leves. Ibid., pp.185-186.

${ }^{42}$ En familia, op.cit., p.16.

${ }^{43}$ Esta dialéctica entre lo que podría denominarse ritmo latente frente a ritmo patente puede observarse en algún otro lugar como, por ejemplo, en el poema perteneciente al libro todavía inédito El que desordena: "Esta ciudad, / llena de perros neutros y de árboles / contrarios y de estanques / con las aguas agrias y organizadas / por la lengua civil de los decretos" (Por detrás de los lápices, op.cit. s. 86) podría recom- 
Aquella patria chica: la intemperie de sus ojos como medallas jóvenes que retuviesen agua en vez de brillo. [...] pudriendo los membrillos, azulándolos [...] para todo el invierno molestando la condenada paz de las despensas

que cohabitan con otro verso no menos complejo como es el alejandrino:

marcados con la saña de lo que bien se sabe

[...]

molidas de repente por la risa y el llanto

Lo cotidiano aparece trasmutado en varios órdenes. La imagen y una métrica agazapada pero efectiva en la consecución de un ritmo desde la naturalidad de la expresión construyen lo que podría llamarse una retórica latente. No menos efectiva es esta retórica en poemas como "Mi padre se hace viejo", ${ }^{44}$ escrito enteramente en endecasílabos blancos, pero desdibujando su marcado ritmo a través de un encabalgamiento que acerca muy bien el ritmo del verso al otro ritmo del habla y del pensamiento. Existe en este poema, que merecería un estudio detenido dada la calidad e intensidad que atesora, un diálogo de voces entre la reconstrucción de la voz del padre y la sabia labor del poeta ahormándola en un verso perfecto, pero humildemente engastado en una apariencia que renuncia al exceso verbal. Lo contenido de estos versos en su formulación métrica, la media voz que protagoniza el poema crean un contrapunto con la conciencia del envejecimiento del

ponerse en otra secuencia en la que se conseguiría una sucesión de endecasílabos: "Esta ciudad, llena de perros neutros / y de árboles contrarios y de estanques, / con las aguas agrias organizadas / por la lengua civil de los decretos". Lo que pretendo insinuar es la posibilidad de encontrar toda un retórica que decide funcionar en un segundo plano, rehuyendo los excesos pero musical y poéticamente muy activa.

${ }^{44}$ Este poema aparece en La secreta labor de cinco inviernos (pp.24-25) y aparece enmarcado entre las fechas de 1979 y 1983 y finalmente es reubicado en En familia, lo que da buena cuenta del carácter orgánico de la concepción del libro que presenta Tomás, aun a sabiendas de su férrea voluntad de publicar anticipos de libros en revistas, prensa, plaquettes y otros territorios provisionales y efímeros antes de la búsqueda de un espacio definitivo. Sobre la relación que existe entre la escritura de este poema y los sucesos vitales que forman la trastienda de esta escritura son especialmente intensas sus palabras en Para qué sirven los charcos, pp.150-151. 
protagonista del poema que podrían ponerse en relación con los mejores momentos del Cernuda final, eso sí, sin la amargura de éste y con la humanidad que encarna la totalidad de la obra de Tomás Sánchez Santiago.

Este balanceo entre lo cotidiano observado desde el extrañamiento y lo crucial examinado con una retórica atemperada plasman, a mi modo de ver, de forma implícita lo que el autor se ha afanado por ir diciendo en diversos textos sobre cómo entiende la escritura. Más ejemplos de cómo lo cotidiano se convierte a través de la mirada del poeta en signo que ha de ser indagado a través del poema pueden ser textos como "Cajeras" o "Metales silvestres" incluidos en su libro Ciudadanía, pero que leo en su antología Detrás de los lápices. En ellos la figura de las cajeras se recubre de una aureola de nostalgia, de figura nocturna que camina a deshoras a contrapelo de los horarios. De lo banal se asciende al terreno de las esencias; el lenguaje poético es una herramienta de la observación, de la comprensión y la humanización a través del sentimiento. En esta línea se dejan leer textos como "Metales silvestres", paradoja sobre la que construye su visión misteriosa del cementerio de automóviles, misterio que crea una atmósfera que finalmente flota en el aire con la pregunta:

$$
\begin{aligned}
& \text { ¿O acaso no sabéis que hay recados siniestros } \\
& \text { y venganzas sin hora y ruidos y calambres } \\
& \text { en todo cuanto un día supo que éramos fuertes? } ?^{45} \text {. }
\end{aligned}
$$

No hay que descuidar cómo esta nimiedad temática es redescubierta a través de la importancia de la imagen y la metáfora, pero también volvemos a encontrar el sólido arquitrabe de una métrica sobre la cual emerge la importancia de lo inadvertido por el uso de las costumbres. El molde del soneto o el endecasílabo distribuido en tercertos que tienden a la rima asonante son un buen medio para comprobar el marcado rigor técnico de algunos de estos textos que trabajan en el fondo y la superficie la manera de redimir lo cotidiano para hacerlo entrañable a los ojos del hombre.

Si ya se ha dado cuenta de la importancia que tiene el uso de las palabras que a veces alojan verdaderos hallazgos de inusitada hondura lírica, es posible examinar la obra de Tomás Sánchez Santiago buscando ese lenguaje que condense en una frase una revelación. Forma parte de esa retórica latente que vengo insinuando. Véase si no el arranque de la parte cuarta de la sección de La secreta labor de cinco

\footnotetext{
${ }^{45}$ Detrás de los lápices. Por detrás dos lápis, Lisboa (Edições Fluviais) p.82.
} 


\section{J.M. Trabado Cabado}

inviernos titulada "Comarca levantada a un solo grito": "La memoria es un grifo malcerrado /donde el pasado vela" (p.66). Sucede que en esta ocasión la revelación experimenta una inercia lírica que dota de continuidad a esa imagen diluyendo en cierta manera ese carácter metafórico y trascendental del aforismo para convertirlo en diálogo consigo mismo, en voz que gira hacia el propio poeta para reconocerlo. Podría ponerse en relación este inicio de texto, catalizador de la escritura poética y la reflexión, con otros textos como el que se incluye en Para qué sirven los charcos: En la incómoda intimidad de los ascensores, todos dialogamos con las llaves (p.125) o Compro unas ramas de dátiles: entra el desierto en casa (p.126) ${ }^{46}$. En éstos existe una intuición formulada linguiísticamente, pero este carácter trunco impide su continuación expansiva a través de fórmulas genéricas como el ensayo o el poema.

Precisamente en este sentido podría examinarse la función que desempeña el entramado genérico por el que discurre la obra de Tomás Sánchez Santiago y ver si es posible establecer un haz de relaciones entre los distintos modelos de escritura propuestos. Como ya se ha argüido, existe una evidente conexión entre una forma de pensamiento, una actitud ${ }^{47}$ y un uso del lenguaje. La preocupación por lo nimio y también por las palabras de la calle traducen bien a las claras la conexión que hay entre una forma de pensar (una poética) y una escritura (creación literaria). Será esa relación entre pensamiento y concepción literaria la que permita establecer los nexos convenientes entre una escritura poética y una escritura ensayístico-narrativa ${ }^{48}$. Como gozne so-

${ }^{46}$ Pueden servir como ejemplos los siguientes: ¡Ah, la monotonía: esa forma de la eternidad! (p.118), Rutina: palabra menuda y sin prestigio. Traficar cada mañana de la nevera a la mesa con la buhonería del desayuno (p.118) o Los cuadros torcidos, ¿son ellos quienes nos están observando a nosotros? (p.95).

${ }^{47}$ Esta palabra, a mi modo de ver, resulta crucial dentro de la poética de Tomás Sánchez Santiago. Me apoyo en textos como el que sigue para mantener lo dicho: Más tarde charlé con otros profesores del asunto central de mi intervención (en clave irónica, la desviada concepción de la poesía por los propios docentes). Creo que noté a algunos incómodos con mi postura de no tratar la literatura como materia didáctica ante la vida con las consecuencias que ello supone, como no calificar o no empeñarse en metodologías historicistas. Ellos no lo entendían así [...] La misión del escritor aunque sea modesto y anónimo, como es mi caso- es escribir. De acuerdo. Pero de cuando en cuando uno debe advertir sobre el destino de lo que hace él y de lo que hacen otros. Al menos para evitar que de aquí a poco tiempo surja una asignatura que denominen Tecnología Poética. En Para qué sirven los charcos, op.cit., p.166.

${ }^{48}$ Son de interés las propias palabras del autor para examinar la diferencias entre el lenguaje poético y el narrativo: En el verso, las palabras se hacen brillantes como si fuesen lucecitas de colorín que se van encendiendo a medida que se leen y permanecen titilando hasta alumbrar todo el poema.; en el relato o la novela, en 
bre el que giran estas dos formas de escritura podría situarse el libro Para qué sirven los charcos que deambula entre el diario, la reflexión literaria o la observación de todo cuanto ve y rodea al escritor. Se instala así en un terreno fronterizo entre lo privado del yo y lo público del pensamiento acerca de la literatura o la reflexión sobre hechos más o menos relevantes que salpican la vida civil. Se trata en definitiva de una forma de autoconocimiento y posterior explicación a los demás de lo averiguado. El yo se analiza en sus circunstancias históricas, pero también sale de su ámbito de privacidad para explicar el mundo que lo rodea. Su forma de declaración de cuanto observa ha de ser tamizada a través del lenguaje, un lenguaje que posee un denominador común, que es el del texto breve, pero en el cual encajan una gran variación formal: desde lo que casi podría considerar greguería hasta pequeñas historias, pasando por breves textos ensayísticos que formulan sus ideas sobre el lugar del escritor, etc. Es una escritura múltiple que bascula entre lo confesional lírico y lo analítico ensayístico. Ambos convergen desde el momento en que uno y otro son discursos sobre el yo ("yo mismo soy la materia de mi libro" había declarado Montaigne en escrito dirigido al lector con el que iniciaba sus ensayos). Estas dos vetas confesional y analítica pueden cristalizar en formulaciones textuales diferentes, pero íntimamente ligadas por un espíritu común. La lírica está transida de un elemento de pérdida, de nostalgia e intento de recuperación de lo ido a través de la palabra. El marco comunicativo va del yo al yo y tiene en el lector a un espectador de ese soliloquio constante que el poeta traza consigo mismo. Por otra parte, esa vertiente de lo analítico y que se desenvuelve dentro de lo civil y lo público aplica esa misma forma de mirar, pero variando ligeramente su objetivo. Se trata ahora de un sujeto situado históricamente frente al yo lírico desubicado en las coordenadas del tiempo. Son los otros los ahora contemplados. El sujeto sale de sí mismo para encontrarse con los demás. La proyección de ese eje tiene lugar en las colaboraciones periodísticas recopiladas en el libro Salvo error u omisión que parten de la mirada atenta sobre el tráfago de la vida para convertirlo, al igual que se hacía en la lírica, en un hondo objeto de reflexión. Evidentemente existen estrategias diferentes para la construcción de la escritura. No se trata aquí de la existencia de esa retórica latente sino de la invocación de otros escritores y otras obras con las que apoyar sus afirmaciones. Se busca entrecruzar la voz destinada ahora al ágora con

cambio, creo que deben incendiarse también, pero para apagarse de inmediato y no estorbar el flujo corriente de la literatura, que no depende tanto de ellas. En Para qué sirven los charcos, p.167. 


\section{J.M. Trabado Cabado}

la de otros pensadores en busca si no de una auctoritas sí de una voz que actúe como caja de resonancia. Así, en el texto "Estas colas" se traen a colación los versos de Historia del corazón de Vicente Aleixandre o en el texto "Parque" se reflexiona sobre el concepto del no-lugar de M. Augé en un mundo como el que nos toca vivir en el que, bajo el anonimato y despersonalización de ciertos lugares que son ahora espacios del tránsito y nada más, todavía se pueden encontrar grupos de ancianos que singularizan ese espacio, aunque sea el de la desmemoria inquietante. El yo que siente se convierte en el yo que mira a las periferias y comprende. Entre lo contemplado y quien observa se levanta una vez más esa forma de conocer basada en la extrañeza, en la creación de cierta distancia que lo convierte en algo anómalo susceptible de ser pensado y convertido en objeto de reflexión que el escritor brinda a los demás en otro alarde de entender la escritura como participación. Sobre esa forma de contemplación se instala en ocasiones una hipertrofia de la observación que desarrolla una tendencia narrativa que llega a asfixiar el elemento reflexivo. Se trata entonces de realizaciones muy cercanas al cuento. Todo ello es comprobable, tal y como advierte el propio autor, en la última sección titulada "Propios y extraños". No existe ahora generalización del asunto, tampoco la cita de otros autores. Son esos recursos de una escritura que germina desde el pensamiento. Ahora lo anecdótico ocupa el protagonismo, pero es algo intransitivo, no es primer peldaño sobre el que construir una reflexión; se trata ahora tan sólo de vieja afición de narrar. A pesar de lo dicho, pueden encontrarse ciertos textos que sirven como transición entre el cuento y el ensayo. Así, por ejemplo, puede leerse "Historia de un mago" que versa sobre cómo un golpe de viento deja al descubierto toda la maquinaria de la que se vale un mago para llevar a cabo sus trucos. Esto provoca una repulsa generalizada por parte de los habitantes del pueblo, repulsa que genera en la mirada de un forastero una honda reflexión construida sobre la relación entre lo latente y lo visible, entre lo maravilloso y la necesidad de eliminar el encantamiento y hacer triunfar la realidad. Ese elemento ensayístico viene dictado en este caso por la inserción de la mirada crítica de un personaje que reflexiona sobre el arquitrabe de una anécdota narrativa: La gente -pensaba el forastero- no soporta el don del encantamiento. $Y$, sin embargo, nunca como ahora se ha vivido menos en la tangibilidad. La voz de los contestadores telefónicos, la virtualidad, el dinero camuflado y abstracto que las tarjetas de crédito contienen, el carácter gaseoso de la identidad de esos anónimos interlocutores con los que se "conversa" en pláticas enmascaradas desde una pantalla de 
ordenador..., todo eso, hoy tan prestigiado, ¿no son en realidad posibilidades de convivir con el misterio? [...] A nadie, no obstante, le importa, de la misma manera que a nadie se le ocurre plantearse que bajo la pátina de un hermoso cuerpo no hay más que un juego hediondo e intestinal de cañerías y tripas repugnantes. No aceptamos asomarnos a las entrañas de las cosas por si su verdad nos mancha ${ }^{49}$.

Las preocupaciones no difieren de lo que en su poética y en la lírica lleva a cabo Tomás Sánchez Santiago: mirar lo que por debajo de las cosas nos quiere hablar, elevar lo aparentemente insustancial a las lindes del pensamiento, la preocupación por lo intangible, recuérdese si no la metáfora del charco como reino de lo inaprensible ${ }^{50}$.

Como puede comprobarse existe un compromiso entre la forma de mirar y la de escribir esa mirada, entre el sentir y el dejar constancia a través de la creación literaria. El yo lírico y el yo ético se hermanan a lo largo de toda la obra estableciendo una tensión diferente que deriva en diferentes articulaciones genéricas que buscan una bisagra en la realización de Para qué sirven los charcos, razón ésta por la que hace de estos textos un ejemplo de difícil adscripción genérica; se trata más bien de una nueva realización de una escritura que busca en su brevedad una capacidad de sugerencia inagotable, un desnortar las brújulas de las clasificaciones, una forma de estar en terreno de nadie o, como diría Julio Ramón Ribeyro, una prosa apátrida.

\footnotetext{
${ }^{49}$ Salvo error u omisión, p.187.
}

${ }^{50}$ Otro texto de Salvo error u omisión incluido en la sección "Propios y extraños" que puede ponerse en relación con la poética aquí esbozada es el titulado "La gotera", que genera en el entramado narrativo un fragmento de naturaleza ensayística: Una gotera hace mucha compañía. En un principio molestaba el chasquido intermitente de la gota contra la palangana que alguien colocó justo debajo. Por lo general, todo lo que nos recuerda el tiempo termina por inquietarnos; no deja de ser un aviso sumarísimo que nos advierte de que también nosotros somos criaturas temporales, sujetos a una duración [...] Así, la gotera se fue haciendo un sitio entre los otros ruidos de la casa. Al lado del patinaje entrompo de la válvula de la olla, del estrépito de la cacharrería del desayuno o del aullido de la aspiradora. Cada poco tiempo (iplof!) caía la gota con su mensaje emboscado de Pulvus sumus. (pp.199-200). Evidentemente este texto narrativiza la idea ya expuesta en el texto, incluido también en Salvo error u omisión, "De lo maravilloso" en el que se daba forma explícitamente a la poética que articula la producción lírica de Tomás Sánchez Santiago. No tan diferente es el texto incluido en Para qué sirven los charcos, en el que lo cotidiano adquiere un trascendencia importante: Cuando esta vecina se pone a aletear las sábanas en el balcón, ¿qué pesadillas o qué sueños improcedentes quiere espantar de casa? ¿Y por qué rendija se colarán en el aire imprevisto de otra alcoba, donde nadie pensaba recibirlos? (p.134). La gotera que recuerda el paso del tiempo, el sacudir la sábanas como forma de espantar pesadillas, el cementerio de coches como una forma de lo ido que pugna por volver con una secreta venganza son formas de expresar lo mismo. 


\section{J.M. Trabado Cabado}

La mirada del escritor proyectada sobre lo cotidiano ensaya al menos tres trayectorias: una que convierte ese referente de lo diario en un objeto simbólico normalmente asociado a un voz lírica cargada de resonancias elegiacas ${ }^{51}$; otra posible dirección ensaya un rumbo ensayístico y supone una toma de conciencia sobre lo que rodea al hombre en una llamada de atención y una última tendencia en la que lo cotidiano queda trascendido por un elemento misterioso que busca lo inquietante, el envés de las $\operatorname{cosas}^{52}$. Estas tres tendencias de lo lírico, fantástico y ensayístico se alternan en un intento por legitimar la vida del día a día y sus objetos como tema propicio para la reflexión y la escritura.

Quizá una buena muestra de cómo estética y ética se dan la mano es el caso del poema "Nuevas preocupaciones" incluido en el reciente libro Lo bastante. El problema radica en que el poeta no sabe dónde colocar las palabras, pero sí dónde encontrarlas. La mirada tiene su territorio perfectamente definido; la actitud ética de la poesía de Tomás Sánchez Santiago sigue vigente desde sus primeros poemas hasta los últimos y pone un énfasis en lo mínimo; sin embargo, el problema reside en la formalización de esas palabras; es decir, en el terreno de la estética, en el tránsito de la mirada al trazo escrito. Así se inicia el poema:

Ya no sé dónde dejar las palabras.

Sé

de dónde tomarlas

todavía:

del picor de las ortigas, del plasma oscuro del aburrimiento, de las lágrimas que cuelgan en los grifos mal cerrados.

$[\ldots]$

${ }^{51}$ Un texto que puede funcionar en este sentido pertenece a Para qué sirven los charcos y lleva como título "El último ejercicio comercial (p.32)": La tienda de ultramarinos del barrio sigue cerrada; la mujer del dueño tiene cáncer y él ha abandonado todo. Pero en los dos escaparates permanecen, impertérritos, los últimos letreros que entre los dos dibujaron: ALUBIAS DE RIÑÓN, LENTEJAS FINÍSIMAS. Paradigmático en este sentido puede ser el texto "Ah, las despedidas" que se inicia de la siguiente manera: ¿De qué sustancia estarán hechas las despedidas? ¿Y cómo espesarán el aire con su carga venial de adioses y de nuncas y de siempres..? Todo el que ha nacido sabe que en algún momento el olor amarillo de las despedidas le va a habitar el corazón, publicado en ABC, viernes, 30/1/2004, p.62.

${ }_{52}$ Sirva como ejemplo el texto de Para qué sirven los charcos: Durante el insomnio de la otra noche me pareció oír la grieta de la pared por dos veces estirarse. Tentadora cremallera que invita a Alicia a pasar al otro lado del espejo (p.79). 
Pero, luego, no sé dónde pararlas, nadie dispone un círculo

de tierra

para que caigan con todo su aliento.

No hay para ellas

temperatura ni sitio

ni estimación ${ }^{53}$.

La misión del poeta será precisamente la de salvar esas palabras desheredadas, algo que se había propuesto en las anotaciones de Para qué sirven los charcos que recogían aquellas formas de hablar que vivían en la marginalidad, pero que se inscribían de lleno en el territorio de la poesía. No era tan diferente ese impulso de hacer inventario de la lírica apócrifa del que se pone de manifiesto en estos versos:

De allí

las voy tomando

y las repongo entre una lentitud de jugos

hasta que ganan miel

en sus nuevas junturas

(la gestión del poeta: rebuscar

por los suelos de la tarde

las palabras desechadas de los hombres) ${ }^{54}$.

La función del poeta es la de la marginalidad en el mirar y en el uso del lenguaje desahuciado ${ }^{55}$ que se intenta redimir del olvido a través de la labor básica de la poesía, del ensayo o de la prosa breve que cristaliza en anécdota no exenta de un toque humorístico. Cuando nadie escucha, el poeta todavía pone atención a esas pequeñas músicas de lo cotidiano que el mundo desoye: "Oigo triunfar su música de fallos. / Nadie las busca". La poesía no es un lujo verbal, constituye en la obra de Tomás Sánchez Santiago una actitud que aúna una forma de pensamiento comprometido con la vida de lo inadvertido y una poética de la desaparición en la que el poeta maneja hábilmente una retórica soterrada y en la que quien escribe desparece tras los meandros de su propia escritura para ofrecer así su pequeño homenaje a lo efímero que acaso sea el reino del hombre y sus pérdidas: lección perenne que

${ }^{53}$ Lo bastante, Cáceres (Alcancía) 2004, p.25

${ }^{54}$ Ibid., pp.26-27.

${ }^{55}$ Escribe en "Música de Astillas": A veces me pregunto si el poeta no será quien emplea las palabras que los demás ya han desechado y repudian. loc. cit. 


\section{J.M. Trabado Cabado}

nos enseña a mirar y saber encontrar los pequeños paraísos anónimos que se ofrecen como mundos inasibles, una vez traspuestos a la secreta música de la poesía:

\section{Llego siempre a buscar lo que ya sólo se halla en la música imposible de las despedidas, en el dulce apagón de las equivocaciones ${ }^{56}$.}

Aquellos charcos que servían al poeta como reflejo de mundos intangibles y misteriosos son muy cercanos a estas "músicas imposibles" en una configuración de la poesía como territorio de lo cotidiano, pero también del desencuentro y de la súbita conciencia de la pérdida. Hay un deambular de la poesía que "tacha / en la memoria la trampa de los nombres / pero salva la música de lo insólito" ${ }^{\text {"57 hasta }}$ esa "música de fallos" de las palabras que forman el verso. Acaso todo tenga la respuesta que el propio autor se da para entender su oficio: perderle el miedo a las palabras ${ }^{58}$ para ofrecer una crónica de cuanto nos rodea en una apuesta por salvarlo todo, aunque sea momentáneamente.

${ }^{56}$ Ibid. p.7.

${ }^{57}$ Detrás de los lápices op.cit., p.88. Es evidente la asociación entre la música y la forma de entender la poesía. En esta línea incide el poema "Uso”: “Cómo se puede tararear un nombre / sin hacer por que su música corrija / los plumajes oscuros de lo dicho, / el uso / que va untando de penumbras las redes / descompuestas / del recado?" El poema puede leerse ahora publicado por la Revista Casatomada, $\mathrm{n}^{\circ} 0.3$, p.21. Esos nombres son empujados por la labor poética "Hacia los abrigos de las melodías". En otro lugar se puede encontrar de forma explícita esa asociación entre nombre-músicapoesía: En realidad, esta imposición del sonido sobre el sentido en la hermosa adhesión que es el hecho de comunicarse tiene que ver más de lo que parece con la poesía, con su hechizo enigmático que sobrepasa los cotos de la razón. Alguna vez, en conversaciones de estirpe literaria hemos dejado caer-medio en broma, pero con alguna intención traviesa- la boutade de que las Escuelas de Traducción deberían ubicarse en algún pabellón anejo a los Conservatorios de Música y no en los alrededores de las Escuelas de Idiomas. Queríamos con ello simplemente apostar por la música del idioma como principal constituyente de su comprensión final, una comprensión que llegaría con más eficacia por la vía cordial de lo que suena por los estrictos vericuetos del silogismo. "Otra vez los nombres", en Salvo error u omisión, op.cit., p.159160.

${ }^{58}$ Para qué sirven los charcos, p.165. 